\title{
KULTUROZNAWSTWO
}

Kamila Budrowska

DOI $10.15290 / \mathrm{sw} .2017 .17 .21$

Uniwersytet w Białymstoku

Wydział Filologiczny

Katedra Badań Filologicznych nad Cenzurą PRL i Edytorstwa

tel.: + 48857457446

e-mail: kamilabudrowska@interia.pl

\section{Censoring the Russian themes in the literature in Poland in the years 1948-1960. Archival reconnaissance ${ }^{1}$}

Key words: Polish literature, censorship, communism, Russian themes

\section{Preliminary remarks}

The present article is based on many years of queries in documents left by GUKPPiW (the Central Audit Office for the Press Publications and Performances) and its subordinate agencies [Budrowska 2009, 2013, 2014]. Researchers from many areas have been interested in the issues of functioning of state censorship in Poland and other former communist countries. Hence, there are historical, philological, bibliologic, and sociological researches [historical: Drygalski, Kwaśniewski 1992; Nałęcz 1994; Krawczyk 1994; Romek 2000, 2010; Pawlicki 2001; Krajewski 2004; Perkowski 2005; Rokicki 2012; philological: Fik 1996; Nycz 1998; Bates 2000; Hobot 2000; Perkowski 2004; Molisak 2004; Budrowska 2009; Woźniak-Łabieniec 2012]. The approach and systematization proposed here are based on philological methodology, although they may be of interest, as well as verified, by researchers in other disciplines.

1 Scientific work financed within the framework of the program of the Ministry of Science and Higher Education called "The National Program for the Development of Humanities" in the years 2012-2017. 
Accepted time frame - having no reflection in any period accepted in history or the history of literature of the postwar period - results from the stage of research and the availability of archival materials. In the period 1948-1960 the harshness of control of literature changed several times. After a relatively gentle (also because of the post-war organizational chaos) years 1945-1948, there were "the darkest" Stalinist years, then came "the thaw" with the mildest censure dated October 1956 - October 1957 [Eisler 1993], and again tightening the shackles of censorship from the beginning of the year 1958. The most interesting seem to be "transitional periods", that is, the end of 1948, the year 1955 and the winter 1957/1958. In those days the mess and the uncertainty of clerks, as to the further political developments, were beneficial to the readers who got the texts that should not have been published at all. The examples are: the most well-known mistake of the year 1955 - Poemat dla dorostych (Poem for Adults) by Adam Ważyk or Odwilż (The Thaw) by Ilya Ehrenburg published and circulated in 100000 copies.

There are a few problem blocks under the expressions "Russian themes" and "censoring the Russian themes". The first is the pre-revolutionary Russia as a theme that appears in Polish or Russian literary fiction, and censoring translations from "classical" Russian literature. The second and when it comes to the weight and the number of archival certificates resulting from it, definitely predominant - is the literary attitude towards the USSR expressed in the texts and, accordingly, censoring Soviet literature translated into Polish.

The review presents the most interesting, from the point of view of literary studies, examples of censorship actions, having profound implications for the development of Polish literature and culture. Actions only postulated or - more frequently - put into practice.

\section{Overview of archive records}

In the study of Dziady cz. II (Forefathers' Eve part II) by Adam Mickiewicz, declared to be issued by the publishing house "Książka i Wiedza", the remarks by the science editor - Henryk Szyper were questioned. One of the most intransigent censors - Renata Światycka wrote in October 1949: "Remarks of a commentator are extremely harmful and inappropriate. The case of Mickiewicz's procrastination with the arrival to Poland during the uprising is presented vaguely, misleadingly; the author is becoming tangled in contradictions. (...) Very vaguely presented attitude to the Russians (emphasis added. - K. B.) [AAN, GUKPPiW, f. 31/39]. The decision to 
issue is negative. It is worth noting that the publishing house "Wiedza" published Dziady drezdenskie (Dresden Forefathers' Eve) and Dziady wileńskokowieńskie (Vilnius-Kaunas Forefathers' Eve) in the same study in 1948. In the autumn of 1949, in connection with the change of control rules, the reissue is not possible due to the charges of inappropriate presentation of the attitude towards the Russians; it is hard to say: the attitude of the editor or Mickiewicz's himself. And so we have in archive records an interesting track of the discontinued edition of the drama, the contribution to the deepening of the research on the reception of romantic literature in Polish People's Republic.

During the increased vigilance of censorship the censors remove from "Pamiętnik Literacki" the poem by Juliusz Słowacki Rozmowa z Matka Makryna Mieczysławska (Talking to Mother Macrina Mieczyslavska) - another outstanding work of the first half of the nineteenth century submitted for publication along with the article about it [AAN, GUKPPiW, 176, 641]. It is worthwhile emphasizing, according to Maria Prussak, that the text by Słowacki was forbidden by the tsarist censorship and as anti-Russian [Prussak 1994, 62-63]. In 1952 passages describing the martyrdom of the Basilian sisters near Vitebsk sounded very present.

In 1958, as is evident from censors' "Sygnały", the Museum of Literature in Warsaw turned to GUKPPiW asking for permission to print posters with two poems by Cyprian Kamil Norwid - Siła ich and Czynowniki [AAN, GUKPPiW, 594, f. 62/2]. Consent was not granted, an anti-Russian meaning of texts was a deciding argument.

They were keeping an eye on anti-Russian elements also in contemporary texts. In 1949 the publishing house "Pallotinum" wants to reissue a historical religious novel Suknia Dejaniry (Deianira's Dress) by Zofia Kossak (the first post-war edition took place in 1948). In a long review signed in Poznań by H. Napierałówna, M.A. on November 26, 1949 among the proposals of many interventions stand out the ones concerning the "Russian" theme, with the suggestion to delete the insulting terms "Moskale" and "Kacapy". The superior decides not to assign paper, therefore the publication does not take place, and the next edition of the book takes place only in 1958 [AAN, GUKPPiW, 173, f. 32/42, p. 33].

In the analyzed period, a lot of translations are from the Russian language. Above all there are translations of the Soviet works, but also classics - albeit in a limited repertoire - have many editions. Interestingly, many Polish writers in the late 1940's and 1950's were deprived possibilities of publishing and took to translating from Russian; finding here safety from a political point of view, "asylum". An example writer is Nadzieja Drucka, 
a Russian by descent, a subject to repressions on account of her aristocratic background.

Censors rarely intervene into translations of Russian classics, but in a way that is very distinctive. In 1949 "Nasza Ksiegarnia" was to publish Pushkin's fairy tale O śpiacej królewnie i siedmiu junakach (About the Sleeping Princess and Seven Swashbucklers). However, censors postulated to cut out religious elements because of "too much speech about God" [AAN, GUKPPiW, 184, f. 31/66]. Interference, characteristic for the period of the socialist realist offensive, was not maintained.

In materials of "Czytelnik" from 1950 one can find a written record of profound ignorance of a clerk controlling the story Pojedynek (The Duel) by a nineteenth-century writer - Alexander Kuprin. Also, it is worth paying attention to the emotional tone of the review. Censor Wołkowicz writes: "(...) Wives of officers are a bunch of horny females with bird's cerebellums. (...) Decades ago Kuprina's work could move the musty burgesses and excite 'salon lionesses' evoking quivers of the scandal and cryptoerotica. (...)". He is still more indignant over the story Ston (The Elephant) about the hysterical girl, who wants and gets a living elephant as a present. "Handing over the work of Kuprina for the evaluation of our Office is a mockery in the most literal sense of the word. (...) it is hard to stop admiration and indignation, that although hundreds of beautiful Soviet fairy tales cannot wait to see fair and artistic translations, the similar kitsch and crime story in every respect, lived to see the honor of the publication en masse, and what's more, by the state-owned publishing house in Poland. (...)" Also, there is a comment of the manager who is granting the permission with a pencil at the bottom: "The short story is included in the II vol. of 'Utwory wybrane'. Absolutely it can be regarded as the humoresque. The work is for adults rather than for children of course" [AAN, GUKPPiW, 145, f. 31/25, p. 202-209].

Huge source material concerning interferences associated with alleged striking in good relations with the USSR requires the stipulation. Describing all situations of controlling work in the brief review is not possible on account of the one very "sensitive" topic, hence we concentrate only on the most interesting examples and the demand for further research in this direction.

It is worth noting that even if the censors did not propose any changes in the controversial text they were always clearly in favor of ("on the side") of the USSR and had fierce polemics with the author. Similar procedures were not practiced with other topics. I would like to recognize it as a kind of defensive strategy (reviews are read by superiors, often members of the Communist Party), needed in case of a rapid change of political winds. An 
example of writing during the thaw is the opinion on, detained over the Stalinist years, a war novel Polska jesien (Polish Autumn) by Jan Józef Szczepański.

After a careful summary of the work, finally issued in 1955 by "Wydawnictwo Literackie" the censor proposes printing without interference, but states that: "(...) in the certain instance an author is committing a serious historical error. Entering of Soviet troops to the areas inhabited by the Ukrainian and Belarusian population took place, according to the work, at a time when the Polish army troops still fought with the invaders, and the Polish government did not escape to Romanian territory yet, i.e. before September $17^{\text {th }}$. (...) This is a major historical inaccuracy and can be used as an argument against a legitimate move of the Soviet government (emphasis added by K. B.), especially that similar attempts have already been made in this direction. It was claimed that it was a 'blow in the back' given by the USSR, etc. The facts presented by the author can suggest it. (...)" [AAN, GUKPPiW, 395, f. 32/12, p. 27-28].

A fragment of an occupation story by Maria Dąbrowska $W$ piękny letni poranek (On a beautiful summer morning) cannot be published in a magazine "Odrodzenie" on April 27th, 1948 . Cut out were the sentences thoughts of the hero about a Soviet prisoner who escaped from a war camp and was eating in the shop with bread: "What a pity ... . What regret, that they gave us so much suffering ... And right now, right now ... What a mistake ... What a pity!" [AAN, GUKPPiW, 29, f. 1/62, p. 9]. The censorship materials did not keep the explanation for the interference, but it can be assumed that the fragment was deemed unnecessary on account of remembering war injustice caused to the Polish population by the Soviet soldiers.

In 1951 - at the behest of the censor - a fragment of a poem by Artur Międzyrzecki Polegtym w ostatnim dniu wojny (Fallen on the last day of the war) was changed. The work was to be published by a publishing house "Czytelnik" in the prepared collection Swiatto nowej dzielnicy. Wiersze (The light of the new district. Poems). The allegation was related to the fact that the poet assigned "equal merit" in the breakdown of fascism to the allies and the Soviet Army [AAN, GUKPPiW, 375, f. 31/28], which sounds odd especially if one remembers that Międzyrzecki fought as a soldier in the $2^{\text {nd }}$ Polish Corps, took part in the Italian campaign and the battle of Monte Cassino.

In 1953 "Czytelnik" wants to reissue the collection of poems by Antoni Słonimski Poezje (Poems) (first edition in 1951). Preserved from this period is the interesting information that demonstrates a specific "fair" among the 
publisher, the author and GUKPPiW. The censor writes: “(...) the publishing house published two poems deleted by censors from the previous edition - 'Na śmierć Majakowskiego' ('To the death of Mayakovsky') and 'Rozmowa $z$ komsomotka' ('Conversation with the Komsomol'). The decision of the superior: "in agreement with comrade Lasson (spelling uncertain) and the author the poem 'Na śmierć Majakowskiego' was removed [AAN, GUKPPiW, 375, f. 31/31]. Reminding the figure of a disappointed poet a communist, who died by committing suicide - must have been unnecessary or perhaps - dangerous to the clerks of Polish censorship in the apogee of the Stalinist era. Just two years earlier in similar circumstances killed was another outstanding writer - Tadeusz Borowski "asphyxiated" by the same ideology.

On March 26, 1954 reviewed was the second revised edition of Popiót $i$ diament (Ashes and Diamonds) by Jerzy Andrzejewski, one of the most widely discussed novels talking about the so-called "Home Army Problem". The proposed circulation was 20175 copies. The case of significant amendments to the text by Andrzejewski, which destroyed ambiguity of the evaluation of attitudes of the Home Army soldiers, had considerable literature on the subject [Detka 1995; Jarosiński 1998; Nowacki 2000; Budrowska 2009]. Here I will only remind you that the author never, despite the adoption in the 1960s of dissident attitude, withdrew them.

While Andrzejewski made the transformations of the text in Popiót $i$ diament independently, most likely only under the influence of changes in beliefs (and he changed them several times), Zofia Nałkowska, which was confirmed by materials, made changes in Węzły życia (Nodes of life) according to the dictates of the clerks censoring the text for her [Budrowska 2014]. After the first edition of the novel in 1948 in a one-volume form the writer encounters difficulties in the next edition of the work. Forced to put many adjustments, ultimately the author decides to extend the text to a twovolume form.

A short story by Wiktor Woroszylski, which was supposed to be published in the May issue of "Twórczość" did not appear. The text Komendant (The Commander) is dedicated to prisoners staying in the labor camp, surrounded by barbed wire and symbolic "black forest", mentioned by a firstperson narrator: "(...) persistently we chopped [it] already the fourth year." [AAN, GUKPPiW, 594, f. 62/1, p. 335]. From the same issue of the magazine two poems on the same topic, written by a former political prisoner Kazimierz Cis were cut out. The first one, Wiosna na Syberii 1955 roku (Spring in Siberia in 1955) dated under the text "Siberia, May 1955", the second $-Z$ pótnocnego poematu (From the Northern Poem), dated: 
"Vorkuta, May 1947," and thus they directly pointed at the long-term stay in a Soviet labor camp.

Moreover, an issue of Polish lands lost in the east in favor of the USSR is a subject which does not escape the vigilance of the office of the control. Here, especially memories of Vilnius and Lvov are being fought. From Wiersze wybrane (Selected Poems) by Kazimiera Iłłakowiczówna, containing works from the years 1912-1945, but submitted for the publication by "Wydawnictwo Zachodnie" in spring 1948 the censor proposes removing as many as 19 texts associated with Vilnius and the religious subjects [AAN, GUKPPiW, 169].

In the summer 1953 "Państwowy Instytut Wydawniczy" is going to publish Wybór wierszy (Selection of Poems) by Konstanty Ildefons Gałczyński. GUKPPiW proposes numerous amendments: ultimately the volume is shortened by over 100 pages, the layout of the whole volume is changed, and a lot of prewar poems are thrown away, allegedly - reclaiming ones [AAN, GUKPPiW, 386, f. 31/124, p. 798-799].

At the end of the archival review there are still "opposite" examples, when taking "Soviet" topics helped to pass through a sieve of control.

The battle of Stalingrad and bravery of the Soviet soldiers are emphasized in the archival materials as important assets of the debut volume by Wisława Szymborska Dlatego żyjemy (Therefore we live) (1952). I am quoting entire fragments of two preserved reviews: "The collection of poems about various subjects: dedicated to fighting near Stalingrad, the heroes of the labor movement who died for the cause, our life and the constructions, the struggle for peace, the struggle of the working class in capitalist countries, the large buildings of communism. Very good, mobilizing, serene poems, very clear, even though touching sometimes gloomy memories; they portray our prospects, urge to fight for peace, show achievements to date.". "It is a book of poetry with the anti-imperialist content. The author condemns fascism and American imperialism, igniting in the reader the disgust and hatred for it and its minions in Europe and around the world. At the same time the author praises the courage of the Soviet soldier who brought the peoples freedom and Peace and thanks to whom the Polish People's Republic came to existence. Literarily and ideologically the poems raise no objections." [AAN, GUKPPiW, 375, f. 31/29]

In "Państwowy Instytut Wydawniczy" there are also two opinions about the volume Wiersze 1940-1952 (Poems 1940-1952) by Adam Ważyk. Shocking is the flattery, not to say obsequious tone, which shows the high political ranking of the writer who was the former political officer in the Tadeusz Kościuszko First Infantry Division. The censors let the volume be 
published without any interference, although in one review there is some regret sounding, from today's point of view, ironically: “(...) The first works of this collection are marked by pessimism, hopelessness. Even life in the Soviet Union failed to inspire the author with hope." [AAN, GUKPPiW, 386 , f. 31/124].

In the 1940s and 1950s most translations were from contemporary Soviet literature [Kondek 1993; 1999]. In the descriptive report on the publishing activities in 1949, next to only one (party) publishing house "Książka i Wiedza" there are in April as many as 11 translations, from which the majority are from the Russian literature, remaining - from languages of other countries of the people's democracy [AAN, GUKPPiW, 77, f. 4/1]. They made a lot of translations for children, for example Jan Brzechwa translated a play for children Teatr Pietuszki (Petushka's Theatre), trying to drive out of the market traditional children's fiction.

During the National Meeting of Heads of WUKPPiW (Provincial Audit Office for Press Publications and Performances) on December 11, 1949 it is stated that Soviet literature is a standard model and should be the template for the newly created Polish literature, at the same time they condemn the "cosmopolitanism" understood as the translation and publication of foreign literature, not Russian literature; in addition English and American works have the worst opinion [AAN, GUKPPiW, 421, f. 4].

At the briefing in June 1951 they minuted, that one of the comrades from the KW (Provincial Committee) was outraged that the censorship clerks proposed changes in the Soviet plays [AAN, GUKPPiW, 421, f. 4].

Such stare and the lack of distance caused the censor's mistake associated with the translation and edition of "Odwilż" by Ilya Ehrenburg in Poland [Budrowska 2009]. The novel was published in the Soviet press in April 1954 and quickly provided the author with fame and reading success. It was one of the first works of Soviet literature in which a new process initiated by the death of Stalin was reflected, it was the illustration of discussion on the new tasks of literature. In the intimate psychological - moral story Ehrenburg focuses on the negative sides of presented reality, showing the consequences which the times of cult of personality imposed on biographies and characters of the heroes. However, the most important creative objective was to tell the right to freely select an artistic road.

The Soviet critics see the work definitely unfavorably. Its author is considered a "nihilist" and "naturalist". Simonov publishes an article stating his program "What you can discuss and what not," in which he criticizes the artist for his destabilizing activities. Attacked Ehrenburg writes a letter (not the first and not the last in his life), to the Central Committee in 
which he asks about the possibility of public defense. He obtains the consent and at the Second Congress of Writers in December 1954 explains his attitude, clearly standing out against the progressive environment of "Nowy Mir". The second part of "Odwilż" is created in the beginning of 1956, artistically fruitless, it will be the fruit of this repentance [Jankowski 1982; Zarzycka-Berard 2002].

In Poland the novel was published by the PIW publishing house in 1955, and the second part - in 1956, translated by Jan Brzechwa and Stanislaw Strumph-Wojtkiewicz. Earlier, a very short piece, along with the information that the novel provoked "a storm of discussion" in the USSR was published in issue 33 of "Głosy znad Odry" in 1955. The page footer indicates that the part I found its way to composition on January 15, 1955, printing was completed very quickly - on March 9, 1955; the part II respectively: June 28, 1956, printing was completed - symptomatically in October 1956. Odwil $\dot{z}$ was published in the Polish translation in the amount of 20000 copies (Volume I) and 10000 copies (Volume II).

The paradox is that the first volume of Odwilz, quickly condemned in the USSR (December 1954), published in Hungary only in the amount of 100 copies intended for high-ranking party officials [Zarzycka-Berard 2002], was published in Poland in such an excessive number. It was influenced by the rapid pace of the censor's work and the fear of correcting or questioning of the Soviet contemporary works. In this one case it worked out good for the Polish reader.

\section{Conclusions}

It appears that controlling the Russian themes in the years 1948-1960 is the priority for clerks of the national censorship. It is indicated by a number of the found examples, out of which only the most interesting ones were presented. Politically it is possible to justify it with the need to keep good relations with the hegemonic leader of the Eastern bloc; hence the strict regulation and careful shaping of the contents associated with the USSR, but also - a bit surprising - with pre-revolution Russia and everything that is Russian. In a country where the history of the nineteenth and twentieth centuries was largely the history of the Polish-Russian and Polish-Soviet conflicts, and where the most outstanding cultural achievements (romanticism) were characterized by deep russophobia, the task before the censors proved to be extremely reckless. And this can be attributed to numerous errors and inaccuracies committed by GUKPPiW clerks: 1 . incomprehension of the 
classical text (Kuprin, Pushkin) 2. watching through the prism of contemporary political situation of works of national poets (Mickiewicz, Słowacki), 3. excessive servility in relation to the authors - communists (Ważyk), or works of social realism (Szymborska, Ehrenburg). 4. far-reaching caution when it comes to the subject of World War II (Dąbrowska, Szczepański, Nałkowska), or time directly post-war (Andrzejewski).

Recognizing the "Russian themes" in the text by censors pushed its real issues off to the background. The work classified in such a way was controlled by GUKPPiW extremely scrupulously, often in discord with intention of the author, searching in detail for references to Russia and the USSR. Censoring the themes described in the article can be considered both as the strategy of assessing on account of inside-text factors (contents of the work), as well as outside-text factors (a reference to the current political situation).

\section{Bibliography}

\section{Archive records}

AAN, GUKPPiW, 29, f. 1/62.

AAN, GUKPPiW, 77, f. 4/1.

AAN, GUKPPiW, 145, f. 31/25.

AAN, GUKPPiW, 146, f. 31/39.

AAN, GUKPPiW, 148, f. 31/66.

AAN, GUKPPiW, 176.

AAN, GUKPPiW, 375, f. 31/28.

AAN, GUKPPiW, 375, f. 31/29.

AAN, GUKPPiW, 386, f. 31/124.

AAN, GUKPPiW, 395, f. 32/12.

AAN, GUKPPiW, 421, f. 4.

AAN, GUKPPiW, 594, f. 62/1.

AAN, GUKPPiW, 594, f. 62/2.

Bates J. M., 2000, Cenzura w epoce stalinowskiej, [w:] "Teksty Drugie", no 1/2, p. $95-120$.

Budrowska K., 2009, Literatura i pisarze wobec cenzury PRL. 1948-1958, Bialystok.

Budrowska K., 2013, Zatrzymane przez cenzure. Inedita z potowy wieku XX, Warsaw.

Budrowska K., 2014, Studia i szkice o cenzurze w latach 40. $i$ 50. XX wieku, Bialystok. 
Romek Z., [ed.] 2000, Cenzura w PRL. Relacje historyków, Warsaw.

Detka J.,1995, Przemiany poetyki w prozie Jerzego Andrzejewskiego, Kielce.

Nałęcz D., [ed.] 1994, Dokumenty do dziejów PRL. Główny Urząd Kontroli Prasy 1945-1949, no. 6, Warsaw.

Drygalski J., Kwaśniewski J., 1992, (Nie)realny socjalizm, Warsaw.

Eisler J., 1993, List 34, Warsaw.

Fik M., 1996, Cenzor jako współautor, [w:] Literatura i władza, ed. SarnowskaTemeriusz E., Warsaw, p. 131-147.

Hobot J., 2000, Gra z cenzura w poezji Nowej Fali (1968-1976), Cracow.

Jankowski A., 1982, Twórczość powieściowa Ilii Erenburga, Kielce.

Jarosiński Z., 1998, Wersje poprawiane, [w:] Autor - tekst - cenzura, ed. Pelc J., Prejs M., Warsaw, p. 39-54.

Kondek S. A., 1999, Papierowa rewolucja. Oficjalny obieg ksiażek w Polsce w latach 1948-1955, Warsaw.

Kondek S. A., 1993, Wladza i wydawcy. Polityczne uwarunkowani produkcji ksiażek $w$ Polsce w latach 1944-1949, Warsaw.

Krajewski A., 2004, Między wspótpraca a oporem. Twórcy kultury wobec systemu politycznego PRL (1975-1980), Warsaw.

Krawczyk A., 1994, Próba indoktrynacji. Działalność MIiP (1944-1947), Warsaw.

Molisak A., 2004, Judaizm jako los: rzecz o Bogdanie Wojdowskim, Warsaw.

Nowacki D., 2000, "Ja nieuniknione". O podmiocie pisarstwa Jerzego Andrzejewskiego, Katowice.

Nycz R., 1998, Literatura polska w cieniu cenzury (Wykład), "Teksty Drugie" no. 3, p. 5-25.

Pawlicki A., 2001, Kompletna szarość. Cenzura w latach 1965-1972. Instytucja i ludzie, Warsaw.

Perkowski P., Cenzura jako źródło cierpień? Powieści Tadeusza Konwickiego $w$ obliczu kontroli słowa; unpublished thesis written at the direction of prof. dr hab. M. Czermińska, Gdansk.

Perkowski P., 2005, Działalność Głównego Urzędu Kontroli Prasy, Publikacji $i$ Widowisk w latach siedemdziesiatych; unpublished doctoral dissertation written at the direction of $d r$ hab. B. Okoniewska, prof. UG, Gdansk.

Prussak M., [ed.], 1994, Świat pod kontrola. Wybór materiałów z archiwum cenzury rosyjskiej w Warszawie, Warsaw.

Rokicki K., 2012, Relacje między literatami a władzami PRL w latach 1956-1970, Warsaw.

Romek Z., 2010, Cenzura a nauka historyczna w Polsce. 1944-1970, Warsaw.

Woźniak-Łabieniec M., 2012, Obecny nieobecny. Krajowa recepcja Czesława Miłosza w krytyce literackiej lat pięćdziesiatych w świetle dokumentów cenzury, Lodz.

Zarzycka-Berard E., 2002, Burzliwe życie Ilii Erenburga. Rosyjski los, żydowskie szczęście, transl. A. Kozak, Warsaw. 


\section{CENZUROWANIE TEMATYKI ROSYJSKIEJ \\ W LITERATURZE POLSKIEJ W LATACH 1948-1960. REKONESANS ARCHIWALNY}

S T R E S Z C Z E N I E

Artykuł oparty jest na kwerendzie archiwalnej wykonanej w zespole GUKPPiW (Głównego Urzędu Kontroli Prasy Publikacji i Widowisk), przechowywanym w Archiwum Akt Nowych w Warszawie. Jego zakres chronologiczny obejmuje lata 1948-1960, co wiąże się z dostępnością źródeł i zakresem przeprowadzonych badań.

Autorka opisuje - na wybranych przykładach - kwestię cenzurowania tematyki rosyjskiej w literaturze pięknej polskiej (XIX-XX w.) oraz tłumaczonej na polski z jezzyka rosyjskiego (XIX-XX w.). Na podstawie opisu losów edytorskich niektórych dzieł Mickiewicza, Słowackiego, Gałczyńskiego, Andrzejewskiego, Szymborskiej, Puszkina, Kuprina, Erenburga dochodzi do kilku wniosków.

Stwierdza, że w interesującym okresie wątki rosyjskie cenzurowane były z najwyższą uwagą i ostrożnością, zawsze w odniesieniu do współczesnej sytuacji historycznej (politycznej zależności od ZSRR). Cenzorzy nie dopuszczali do prezentowania prawdy historycznej, bez zrozumienia czytali klasyków, z atencją traktowali natomiast pisarzy - komunistów. O sposobach kontrolowania tematyki rosyjskiej w latach 1948-1960 decydowały zawsze czynniki wobec tekstu zewnętrzne. 